\title{
Analýza potřeb studentů odborného francouzského jazyka v př́ípravě na pracovní stáže ve Francii
}

\author{
Needs analysis of students of French for specific purposes in \\ preparation for work mobility in France
}

\author{
Hana Delalande
}

\begin{abstract}
Abstrakt: $V$ příspěvku je představen kontext disertačního výzkumu, jehož cílem je zmapovat náplň pracovních stáží českých a slovenských studentů ve francouzských institucích veřejné správy, identifikovat komunikační situace, do kterých se studenti během stáží dostávají, a definovat úlohy, které musí řešit. Na základě rozhovorů se studenty francouzsko-českého studijního programu ESF MU Veřejná správa (Administration publique) bezprostředně po ukončení pracovní stáže byly v rámci pilotního výzkumu v roce 2018 identifikovány problematické situace a okruhy a analyzovány z hlediska potřeb chybějících v předcházející přípravě. V závěru příspěvku jsou prezentovány možnosti zefektivnění přípravy na stáže a další kroky disertačního výzkumu.
\end{abstract}

Klíčová slova: analýza potřeb, komunikační situace, odborný francouzský jazyk, pracovní stáže, rozhovory

\begin{abstract}
The article treats context of a doctoral research whose goal is to gather information on the content of internships of Czech and Slovak students in French public administration institutions, to identify communication situations the students get into and the tasks they have to complete. A pilot research based on interviews with the sample of students of the French-Czech study program Public administration (Administration publique) of the Faculty of Economy and Administration that were carried out shortly after the end of the internships in 2018 and problematic situations and topics were identified and analyzed in the view of elements missing in the preparation prior to departure. At the end of article, possibilities of improvement of preparation of the students before their departure and the next steps of the doctoral research are discussed.
\end{abstract}

Key words: communication situations, French for specific purposes, internships, interviews, needs analysis

\section{1 Úvod}

Již od doby komunikačního přístupu plní vyučující cizích jazyků roli těch, kteří analyzují potřeby jazykového vzdělávání studentů a výuku přizpůsobuje výsledkům těchto analýz na základě strategií učení, cílů a potřeb studentů (Richards \& Rodgers, 2014, s. 99), což v kontextu výuky odborného, resp. ekonomického cizího jazyka na vysokých školách platí dvojnásob. Aby výuka mohla být efektivní, je třeba se soustředit na to, co absolventi v pracovním prostředí konkrétně potřebují, do jakých situací se dostávají ve formální i neformální komunikaci, at' už 
s kolegy nebo se zákazníky. Př́mé propojení univerzitního vzdělávání a trhu práce a hledání konkrétních vzdělávacích potřeb studentů na základě jejich zkušeností z pracovního prostředí zdůrazňují taktéž odborné studie z posledních let (Dvořáková, 2018; Pégaz-Paquet, 2016; Trofin, 2018). Pro zvýšení efektivity výuky je vhodné se při používání jazyka ve tř́dě co nejvíce přiblíziit tomu, jak budou studenti jednou sami cizí jazyk v praxi používat. Tuto realitu je možné zmapovat na základě výzkumného šetření, a to např́iklad zkoumáním používání cílového jazyka absolventy nebo zkoumáním zkušeností studentů během pracovních stáží. V tomto článku se tedy budu zabývat problematikou přípravy na pracovní stáže českých či slovenských studentů do francouzského pracovního prostředí.

\section{Přehled dosavadního poznání}

Termín odborný jazyk označuje „systém jazykových prostředků, jejichž výběr a uspořádání slouží $\mathrm{k}$ ústní nebo písemné komunikaci odborného obsahu vědeckého, technického či jiného" (Hendrich, 1988, s. 119). Odborným jazykem tedy rozumíme soubor všech jazykových prostředků, které se v daném oboru používají. Ve francouzském jazyce existují pro odbornou francouzštinu termíny jako français de spécialité, français spécialisé, français professionnel nebo français sur objectif spécifique (FOS). První tři termíny lze chápat jako ekvivalentní výrazy odpovídající českému pojmu odborný (francouzský) jazyk: důraz je kladen na odbornost (francouzský jazyk pro lékaře, právnická francouzština apod.) nebo na odvětví (turismus, hotelnictví, bankovnictví, obchod, diplomacie apod.), zatímco termínfrançais sur objectif spécifique, česky francouzština pro specifické účely, lze považovat za pojem obecný a nadřazený, protože specifickým účelem nemusí být nutně dosažení odbornosti v určitém vědním oboru (Carras et al., 2007, s. 18-20; Mangiante \& Parpette, 2004, s. 16-17).

Co se týče francouzštiny pro specifické účely (FOS), ta je dle Mangianta a Parpetteové (2004) jednoznačně definována na základě poptávky. Autoři nabízejí schéma o pěti etapách: 1) poptávka po jazykovém vzdělávání, 2) analýza potřeb, 3) sběr dat, 4) analýza dat a 5) tvorba didaktických aktivit. Často jde o krátkodobé vzdělávání s obsahem, který učitel neovládá a při př́ípravě vzdělávacích aktivit je třeba spolupracovat s aktéry z daného odvětví.

Cílová skupina odborné francouzštiny je oproti FOS širší. Výuka odborného jazyka není připravována na základě nějakého přesného zadání či poptávky jako u FOS, ale je připravována pro potřeby studentů s ne úplně jasným, spíše hypotetickým účelem. A právě odborným jazykem a jeho výukou na vysoké škole ekonomického zaměření se budu zabývat ve své disertační práci. Studenti obchodní francouzštiny se vzdělávají $\mathrm{v}$ ekonomických předmětech $\mathrm{v}$ rodném jazyce a zároveň se učí odbornému obchodnímu jazyku, aby ho mohli v budoucí profesi používat, ve styku 
s francouzskými protějšky nebo při práci ve francouzských nebo jiných mezinárodních firmách.

Ve své disertační práci vycházím z již uskutečněných výzkumů, ve kterých jsou zkoumány zkušenosti studentů či absolventů v praxi a které se otázkou efektivní př́ípravy na budoucí práci studentů zabývají (Kovářová, 2014; Myles, 2009; Nikyema \& Henry, 2009; Peyrard-Zumbihl, 2004). Většina autorů se zabývá studenty či absolventy, jejichž cílovým jazykem je odborná angličtina. Mylesová (2009) analyzovala zkušenosti čínských studentů v Kanadě, kteří během studií absolvovali šestnáctiměsíční pracovní stáž. Výzkumnice se zaměřila na situace, které byly pro studenty $\mathrm{v}$ daném pracovním prostředí problematické a na jejichž základě navrhla konkrétní doporučení toho, co by do výuky odborného jazyka mělo být zařazeno. Podobné, ovšem rozsáhlejší projekty byly realizovány francouzskými technickými univerzitami a zahraničními firmami ze sedmi evropských zemí ${ }^{1}$ v tzv. Projektu Valeurtech (Nikyema \& Henry, 2009) a v rámci disertačního výzkumu na univerzitě v Nantes (Peyrard-Zumbihl, 2004). Autoři na základě výzkumů pro studenty francouzských technických univerzit navrhli vzdělávací moduly vyučované $\mathrm{v}$ angličtině, tzv. př́pravu na mezinárodní pracovní mobilitu. Do modulu byly zapracovány nejen konkrétní zkušenosti stážistů, ale také očekávání a požadavky ze strany zahraničních poskytovatelů stáží.

Výzkum, který se specializoval na francouzské pracovní prostředí, byl uskutečněn v České republice v roce 2013 jako součást projektu Interkulturní dimenze v podnikové kultuře nadnárodních firem - komparativní studie. Do projektu byli zapojeni studenti VŠE v Praze, francouzské nadnárodní i menší a střední podniky se sídlem v ČR, přičemž se zjištovaly interkulturní rozdíly v řízení společností a v chování zaměstnanců. Na základě výsledků výzkumu pak výzkumníci z VŠE reflektovali metody a techniky rozvoje interkulturní komunikační kompetence ve výuce odborného francouzského jazyka. Konkrétním výstupem pak byly didaktické materiály, např. př́ípadové studie ${ }^{2}$ či globální simulace ${ }^{3}$ (Kovářová, 2014; Dvořáková, 2018).

\footnotetext{
${ }^{1}$ Belgie, Finsko, Portugalsko, Rumunsko, Řecko, Slovinsko a Spojené království.

2 Zde uvádím dva př́iklady případové studie, které Kovářová vypracovala: „Vítáme vás, nová vedoucí, v pobočce francouzské firmy v Praze“ nebo „Pracuji v Pařiži, jak to přežít?“ Na základě zadání určitého interkulturního problému nebo konfliktu student analyzuje danou situaci, odpovídá na otázky a vypracovává zadané úkoly.

${ }^{3}$ Ve fr. jazyce simulation globale (Yaiche, 1996): na základě podrobného zadání reálné situace si studenti rozdělí role a řeší konkrétní úkoly. Např. plánují a realizují expanzi společnosti, ve které pracují. Nabírají nové zaměstnance, zařizují nové kanceláře a definují projekty, na kterých bude nová divize společnosti pracovat. Studenti během těchto aktivit prokazují znalosti interkulturních rozdílů v řízení společnosti a chování zaměstnanců.
} 


\section{Metodologie}

Cílem disertačního výzkumu, ze kterého předkládaný příspěvek vychází, je zmapovat náplň pracovních stáží českých a slovenských studentů ve francouzských institucích, identifikovat komunikační situace, do kterých se studenti během stáží dostávají, a definovat úlohy, které musí řešit. Za účelem ověření výzkumného nástroje a metodologického postupu byl v roce 2018 realizován předvýzkum, jehož výsledky a zjištění budou představeny v následujících kapitolách. Problematické situace zde budou analyzovány z hlediska komunikačních potřeb chybějících v předcházející přípravě.

Design pilotního výzkumu byl kvalitativní a vycházel ze zakotvené teorie (Grounded theory method), která je založena na zakotvení teorie $\mathrm{v}$ datech, která byla během výzkumu získána (Corbin \& Strauss, 2015, s. 14). Hlavním nástrojem sběru dat byl polostrukturovaný rozhovor.

Výzkumný vzorek předvýzkumu tvořili studenti navazujícího magisterského programu Veřejná správa (Administration publique) na Ekonomicko-správní fakultě Masarykovy univerzity, nazývaný také MFTAP (Master franco-tchèque d'Administration publique), který vznikl v roce 1999 spoluprací Masarykovy univerzity a francouzské Université de Rennes 1 . Studenti tohoto programu během 3. semestru studia vyjíždějí do francouzského města Rennes na povinnou dvouměsíční pracovní stáž v institucích veřejné správy. Vedle stáže ve Francii před odjezdem do Rennes již absolvovali měsíční stáž v instituci české veřejné správy. Pilotní výzkum byl realizován v prosinci 2018, tj. jeden týden po ukončení pracovní stáže a zúčastnilo se 12 studentů české a slovenské národnosti (z celkového počtu 13 studentů dané studijní skupiny). Ve čtyřech př́ípadech studenti rozhovory absolvovali ve dvojicích (mluvil vždy jeden student, druhý byl rozhovoru přítomen a poslouchal výpověd' kolegy či kolegyně, poté se vyměnili), zbylé 4 rozhovory byly nahrány individuálně. Délka rozhovorů byla v trvání od 10 do 38 minut.

Témata, která byla pro rozhovor připravena a systematicky rozhovory prolínala, byla náplň stáže, komunikační situace (formální i neformální) a obtížné situace či překvapivé momenty, resp. (ne)dostatečnost přípravy na ně. Pokud studenti chtěli, mohli se navíc volně vyjádřit $\mathrm{k}$ jakýmkoliv aspektům stáže. Rozhovory, které byly se svolením účastníků výzkumu nahrávány na diktafon, byly později transkribovány a analyzovány metodou tužka papír ve fázích, které jsou pro zakotvenou teorii obvyklé: tvorba konceptů při otevřeném kódování, hledání teoretických vztahů mezi kategoriemi a volba ústředního konceptu (Řiháček \& Hytych, 2013, s. 47). Na základě zjištění z pilotního šetření byla mírně upravena metodologie pro hlavní část disertačního výzkumu, který probíhal v roce 2019, a který bude v následujících kapitolách také zmíněn. 


\section{Výsledky a jejich interpretace}

Na začátku rozhovoru jsem zjištovala identifikační charakteristiky každého studenta. Co se profilu týče, jednalo se tedy o studenty následného francouzsko-českého magisterského programu Veřejná správa. Studenti byli do studia přijati na základě přijímací zkoušky z veřejné ekonomie, veřejných financí, všeobecného přehledu a znalosti francouzského jazyka, přičemž byla požadována minimální jazyková úroveň B2. Studenti byli ve věku 23 až 25 let, až na jednu výjimku měli všichni předchozí zkušenost ze studijního pobytu v zahraničí, ve dvou případech měli studenti dokonce zkušenost z pracovní stáže ve Franci a Belgii.

\subsection{Obsah stáží}

Studenti vykonávali stáže v různých institucích francouzské veřejné správy, s poměrně širokým zaměřením: od mezinárodních oddělení univerzit, přes prefekturu, neziskové organizace, po oddělení banky, která měla za úkol poskytovat úvěry a půjčky pro územní samosprávní celky. Pro organizace to, až na jeden případ, nebyl první kontakt s českým stážistou vyslaným univerzitou. Studenty na stáže umistovala francouzská univerzita. Studenti v předchozím semestru studia vypracovali životopis a motivační dopis a vyplňovali žádosti o umístění na stáž, ve kterých měli příležitost vyjádřit vlastní preference, závěrečné rozhodnutí ale zůstalo $\mathrm{v}$ gesci francouzské strany.

Co do obsahu stáže, studenti se zmiňovali o široké škále témat a aktivit, které mohou odpovídat rozmanitosti institucí, ve kterých studenti pobývali. Na starosti měli např̀ organizaci kulturních událostí, organizaci zahraničních pracovních stáží pro francouzské středoškoláky, různé administrativní úkoly, zadávání údajů do databází, ale také vysoce odborné úkony jako např. finanční analýzu územních samosprávních celků a práci s rozpočtem a účetními výkazy. Vedle toho se studenti účastnili schůzí, workshopů a konferencí, v několika případech na nich aktivně vystupovali či workshopy sami připravovali a moderovali. Někteří studenti také připravovali a zveřejňovali články na sociálních sítích, ve kterých se zmiňovali o zajímavostech z České republiky a o francouzsko-českých vztazích.

Všichni studenti měli v první fázi stáže za úkol si prostudovat dokumentaci o dané instituci veřejné správy a o úkonech, kterými se instituce zabývala. Vedoucí stáží tuto fázi, která ve většině případů trvala v řádu několika dní či jednoho týdne, považovali za nezbytnou pro to, aby bylo studentům umožněno vykonávat vlastní, samostatnou práci. K dispozici měli řadu odborných textů, jako např. zákony, výroční zprávy ale také „rapporty“, tj. závěrečné zprávy ze stáží předchozích studentů stejného studijního programu.

V jednom případě student vlastní stáž popsal jako „pozorovací“ (stage d'observation), kterou považoval za značně pasivní, nebot' fáze studia odborné dokumentace 
trvala po celou dobu stáže a student, na rozdíl od ostatních kolegů, samostatné úkoly či vlastní program stáže nedostal. Daný student při rozhovoru svou zkušenost srovnával s náplní stáží ostatních studentů oboru. Studenti celého ročníku totiž na stáž vyjíždějí ve stejném termínu do stejného města, jsou ubytovaní na stejných univerzitních kolejí, ačkoliv stáže vykonávají každý v jiné instituci. Studenti se po celou dobu pobytu ve Francii setkávají, o zkušenostech ze stáží diskutují, je tedy možné, že student svou náplň stáže v důsledku srovnávání s kolegy hodnotil až př́liš negativně, tak jako $\mathrm{S}^{4}:$,... nic, já jsem prostě jenom seděl v kanclu čekal, čekal, až mě vedoucí vezme někam, někam na réunion, kde jsem ničemu nerozuměl, takže. Nic jsem tam nedělal, fakt vůbec nic“. Tentýž student ale dále $\mathrm{v}$ rozhovoru popisoval, jak $\mathrm{v}$ druhé polovině stáže při práci na závěrečné zprávě dělal rozhovory s kolegy z ostatních oddělení a pracoval na uceleném popisu a analýze fungování dané instituce.

\subsection{Formální i neformální komunikační situace}

Studenti se dostávali do četných komunikačních situací, a to jak formálních, tak neformálních. Studenti měli na všech pracovištích k dispozici vlastní pracovní místo $\mathrm{s}$ počítačem a emailovou adresou, kterou ve své práci používali. Byli v písemném kontaktu s vedoucím stáže a s kolegy $\mathrm{z}$ dané francouzské instituce, ale také s partnerskými institucemi a veřejností. Komunikace byla taktéž ústní, a to jak s vedoucím stáže a kolegy na pracovišti, tak i telefonicky s francouzskými i zahraničními partnerskými institucemi i veřejností.

Pokud jde o neformální komunikaci, studenti se s vedoucím stáže a kolegy nejčastěji setkávali během přestávek na kávu či na oběd. Ve francouzském pracovním prostředí je „pause café“ v mnoha organizacích a institucích považována za formální neformální př́ležitost pro komunikaci spolupracovníků a udržování dobrých mezilidských vztahů na pracovišti, protože je často organizována v pravidelných intervalech. Studenti mají během těchto neformálních situací př́ležitost setkat se i s kolegy ze vzdálenějších kanceláří, představit se jako kolega stážista, ale také kolega stážista ze zahraničí. Studenti ve výzkumných rozhovorech uváděli, že se mezi tématy neformální konverzace s kolegy objevovalo: studium, rodina, cestování, národní svátky, kultura, náboženství, historie České republiky nebo Československa a ekonomické souvislosti historických událostí, aktuální politické dění nebo interkulturní rozdíly mezi Francií a Českou republikou v různých aspektech každodenního života.

${ }^{4}$ V ukázkách použivám zkratky S1, S2, atp. jako student/ka 1, student/ka 2. 


\subsection{Problematické situace}

Mezi situace a aspekty stáže, které studenti sami označovali za problematické, patří nedostatečná odbornost a znalost odborné slovní zásoby v konkrétní specializaci, což byl př́ípad zejména studentů na vysoce specializovaných pracovištích. Studenti dále upozorňovali na neschopnost pohotově reagovat $\mathrm{v}$ konverzaci a vyjádřit se $\mathrm{k}$ určitému tématu $\mathrm{z}$ důvodu nedostatečné slovní zásoby, znalostí a všeobecného kulturního a historického přehledu, ale i návyku na toto téma plynule konverzovat, jak popisuje S1: „Jako člověk najednou není schopný to předat, protože tu slovní zásobu nemá, ani nějak neví, jak to v hlavě poskládat“. Stejná studentka S1 se také o dalším problematickém aspektu: „Na začátku bylo nejhorší, když se mě ptali na Českou republiku, protože jsem zjistila, že třeba v tý francouzštině popsat nějaký historický vývoj a proč se rozpadlo Československo, tak to teda nebylo úplně jednoduchý." Je zajímavé, že studenti zmiňovali situace, především neformální, kdy měli francouzským kolegům přiblížit určité momenty z historie Československa či České republiky (např. srpen 1968, listopad 1989, rozpad Československa v roce 1993 a ekonomický vývoj České republiky po roce 1993 a vstupu do Evropské unie), ale nebyli schopni se k danému tématu vyjádřit, i když sami tvrdí, že určité znalosti o daných tématech mají. V přípravě na stáž ve francouzském jazyce se většinou okruhy z české a československé historie neprobírají, nebo pouze okrajově.

Studenti také upozorňovali na vlastní neschopnost samostatně pracovat nebo efektivně spolupracovat s ostatními kolegy z pracovního týmu. Dle vlastních slov měli potíž najít rovnováhu mezi tím, aby mohli pracovat sami, na základě vlastní kreativity, ale zároveň se ujistili, že stále splňují původní zadání úkolu. I když dle studentů francouzští vedoucí stáží zdůrazňovali, že jsou studentům k dispozici pro př́ípadné konzultace a dotazy, studenti se obávali, aby vedoucí neoslovovali př́liš často a nepůsobili nesamostatným dojmem, jako v případě S3: „Ta autonomie byla nepř́ijemná, no, já jsem to pochopil po svém, snažil jsem se na to přijít sám, aniž bych se na to ptal kolegyní, aby mi s tím pomohly. A to mi potom bylo často vyčítané, že jsem $\mathrm{k}$ něčemu dospěl, nezeptal se na názor a zkoušel jsem to řešit sám."

\subsection{Nedorozumění}

Studenti taktéž pocitovali počáteční nedůvěru ze strany vedoucích a kolegů, a to zejména v první fázi, kdy měli studovat velké množství materiálů o dané instituci, jejích pravomocech a běžné agendě. Pro mnohé francouzské kolegy to byla první př́ležitost setkat se na pracovišti s osobou z České republiky. S5 říká: „Francouzská stážistka mi pak říkala, že když se dozvěděla, že bude pracovat s Češkou, ř́kala si, jak se s ní domluvím, o čem si budeme povídat? To přeci vůbec nepůjde." Spolupráce s francouzskými kolegy přinášela taktéž v některých případech př́ikla- 
dy neporozumění, jako v př́padě nevhodného vtipkování studenta S3: „Stala se jednou situace, že jsem to přehnal. Když si ze mě dělali srandu, tak jsem to vůbec nevnímal negativně. Ale jednou se mi stalo, že když jsem si udělal z někoho, z konkrétní osoby srandu, tak to brali jako urážku. Vlastně toto mě u těch Francouzů dost překvapilo, že je třeba si dát pozor na to, co říkáte." Dále si studenti nebyli jistí při výběru vhodného pozdravu a vhodného tématu konverzace, jako např. S8: „Co bylo těžký, to bylo to podávání rukou nebo bises/polibek na tváŕ a to, že člověk neví, co má ř́kat, o čem mluvit“. Kulturní a společenské zvyklosti cílové země se sice v přípravných kurzech obvykle probírají, ale součástí kroků od teorie k praxi bývají i tyto zmíněné nejistoty.

\subsection{Očekávání a prožívání stáže}

Studenti se taktéž zmínili, že původně očekávali značně rozdílnou náplň stáže. Měli rozdílné představy, založené především na vyprávění studentů předchozího ročníku a jejich zkušenostech. $V$ těchto případech prožívali pocity zklamání, jako S6: „Jsem z té stáže zklamaný. Věděl jsem, že loňská studentka byla v mé organizace velice spokojená, dělala tam strašně moc věcí, bylo to různorodý. Takže jsem se strašně těšil, že budu mít něco podobného, pak to bylo zas úplný opak". Student si pak, ve srovnání se spolužáky, připadal velice zbytečný: „Hodně těžký bylo, že jsem tam nic nedělal. Já jsem vlastně věděl, že tam nic nepřináším, té organizaci, to mě teda hrozně mrzelo. Každý ráno, když jsem tam jel, tak se mi strašně nechtělo. Věděl jsem, že tam budu sedm hodin sedět a čekat, až budu moc jít domů." Jiní studenti měli naopak pocit velkého tlaku a zdálo se jim, že jsou prací zavaleni, S9: „Nejsložitější bylo hodně úkolů naráz. Strašně moc různých úkolů, v různých časových úsecích, občas těžko zkloubitelných. Já jsem stresař, bylo to na začátku dost stresující, pro mě“. Studentka měla za úkol odpovídat na dotazy obcí na legislativní změny. „Třeba odpovědi na ty otázky z obcí, na to byla pětidenní lhůta, když jsem čtvrtý den nevěděla, co $\mathrm{s}$ tím, tak jsem se chodila ptát těch ostatních. Vedoucí i jeho podř́izená toho měli hodně a negativum bylo, že když to nestíhali, tak to na nás, nechci ř́ct, házeli, ale hodně věcí na nás delegovali." Tatáž studentka později o nejtěžších úkolech mluvila z jiné perspektivy: „To nejtěžší se mi pak ke konci zdálo jako nejlehčí, nejzábavnější. To byly právě ty arrêtés. Já jsem je nesnášela, nechápala jsem tu strukturu, všechny měly jiný prŕlohy, ale pak jsem pochopila ten postup, každý byl jinej, bylo to občas docela zábavný, to mě bavilo." Na těchto zkušenostech je možné ilustrovat různé prožívání složitých situací během stáží a různé strategie, jak se s danou situací vyrovnat, tzv. copingové strategie (viz Anderson, 1994). Zatímco někteří studenti volí strategii participace a aktivního postavení se problému, role jiných studentů může být pasivní, připomínající strategii „time-serving“, tedy jakéhosi „přežívání“.

Studenti také pozitivně hodnotili př́stup francouzských kolegů. Hierarchie se jim zdála pouze formální, nebot' necítili rozdíly v chování kolegů vưči českým stážis- 
tům, francouzským stážistům a jiným kolegům a spolupracovníkům. Dále oceňovali radost francouzských kolegů z práce a zapálení pro věc, což v českém pracovním prostředí zatím $\mathrm{v}$ takové míře nepoznali.

\section{Diskuze}

V této části bych se ráda zamyslela nad tím, co by se dalo ve výuce odborné francouzštiny upravit a jak efektivněji studenty připravit na budoucí práci. $\mathrm{Z}$ analýzy dat je patrné, že obsah stáží je tak široký s paletou různých úkolů, že není v silách vyučujícího reagovat na všechny podněty. Je však možné, aby vyučující na základě výše uvedené analýzy potřeb studentů během stáží vybral alespoň dvě nebo tři rozdílné instituce a připravil praktické úkoly, jako napřs simulace řešení zvoleného problému.

Protože všichni studenti během stáží pravidelně písemně komunikovali s různými korespondenty, začlenění témat obchodní korespondence se rovněž zdá být na místě. Vyučující může se studenty pracovat na jazykových obratech, které jsou pro písemný projev vhodné, a na zvláštnostech, které jsou pro obchodní styk obvyklé. Studenti se tak budou v praxi méně soustředit na formální nedostatky a typické obraty, které si ve výuce již osvojili, ale zaměří se na strukturu a obraty specifické pro místo výkonu stáže. Jinak je třeba odpovědět na oficiální požadavky obcí a jinak bude formulována pozvánka na setkání Erasmus studentů. Praktický nácvik písemné práce dle francouzských norem (analýza, syntéza) se bude studentům hodit také při př́pravě prezentací, workshopů, ale i závěrečné zprávy, kterou studenti po skončení stáže obhajují před komisí.

Dle výpovědi studentů nelze předem ovlivnit, zda se dostanou na pozorovací stáž nebo na stáž velmi praktickou a náročnou na počet úkolů. Vyučující francouzského jazyka ale se studenty může nacvičovat př́klady vyjednávání a diplomatického postupu. Studenti by si tak mohli vyzkoušet nebo nacvičit komunikační situace, ve kterých si chtějí o dané věci promluvit s vedoucím. Mohou se naučit vyjednat si jiné pracovní podmínky, a to v obou (extrémních) případech, tedy když se student na pasivní stáži bude chtít domluvit na konkrétní a praktické úkoly, nebo naopak zdvořile a efektivně vysvětlit, že nebude schopen pracovat $v$ tak rychlém tempu, zavalen úkoly, které jsou pro něj náročné.

Vyučující odborné francouzštiny může se studenty taktéž nacvičovat neformální konverzaci na různá témata, nejen na ta, kterými si je student jistý, ale i zájmově vzdálené oblasti. Studenti programu MFTAP se v prvním semestru studia věnují př́pravě životopisu, motivačního dopisu a rozvoji komunikační dovedností, ale zaměřují se výhradně na reálie spojené s Francií. Avšak jak se již píše v učebnici Miroirs et fenêtres - Manuel de communication interculturelle ${ }^{5}$ (Huber-Kriegler et

\footnotetext{
5 Doslova Zrcadla a okna: učebnice interkulturní komunikace.
} 
al., 2003). Metoda učebnice je založena na předpokladu, že ještě před tím, než vyhlédneme $\mathrm{z}$ okna a objevujeme kulturu cílového jazyka, je třeba si uvědomit svou vlastní kulturu, tj. pohlédneme do zrcadla. Dle dosavadních zjištění je patrné, že jsou čeští studenti považování za vyslance české kultury, pojítko mezi Francií a zemí, kterou zatím kolegové neznají, ale mají zájem se o životě v ČR dozvědět víc. Při studiu veřejné ekonomie nebo evropské integrace (předměty v sylabu studijního programu) mohou studenti více dbát na porozumění českého kontextu vstupu do EU, jeho následky, dále by měli umět přemýšlet nad ekonomickým dopadem rozpadu Československa.

V reakci na zjištěná interkulturní nedorozumění či incidenty by vyučující mohl do výuky zavést téma aspektů interkulturní citlivosti, věnovat se rozdílům v kulturách, ale také si uvědomit různé způsoby vlastního prožívání mezinárodní mobility a schopnost adaptace $\mathrm{v}$ novém prostředí. Vhodné by bylo taktéž posouzení skladby předmětů $\mathrm{v}$ prvním ročníku a případné rozšíření výuky odborného francouzského jazyka i do druhého semestru studia MFTAP a poskytnout tak studentům více př́ležitostí pro jazykovou a interkulturní přípravu na pracovní stáž.

Co se týče metodologie, $v$ dalších fázích výzkumu bude vhodné, aby výzkum probíhal v průběhu celého pracovního pobytu, tudíž, aby se rozhovory realizovaly na začátku stáže, uprostřed a po jejím ukončení. Důležité pak bude, pokud to bude možné, realizovat závěrečný rozhovor s časovým odstupem např. šest měsíců. Velice potřebnou a obohacující součástí vzorku budou taktéž francouzští vedoucí stáží, kteří do výzkumu přinesou vlastní pohled na dané téma a budou se moci vyjádřit $\mathrm{k}$ požadovaným kvalitám studentů, $\mathrm{k}$ náplni stáží, příp. i k dalším okruhům vhodným zařadit do př́pravných kurzů, včetně různých aspektů interkulturní spolupráce.

\section{Závěr}

Z výše uvedeného je patrné, že propojení univerzitního prostředí s praxí na trhu práce je potřebné. Poznatky z analýzy potřeb studentů vyjíždějících na stáže do francouzských institucí veřejné správy, založené na konkrétních pracovních zkušenostech studentů v cizojazyčném prostředí, je pro vyučující odborného cizího jazyka vhodným zdrojem informací, které jsou potřebné pro zefektivnění výuky odborného jazyka. Zaměření se na problematické okruhy i na rozvoj interkulturní kompetence by mohlo studentům a absolventům ekonomických oborů pomoci lépe se připravit na praktické používání jazyka v každodenní praxi na pracovišti a snížit tak případný kulturní šok.

\section{Literatura}

ANDERSON, L. (1994). A new look at an old construct: Cross-cultural adaptation. International Journal of Intercultural relations. 18, 293-328. 
CARRAS, C., Tolas, J., Kohler, P., \& SzILAGYI, E. (2007). Le français sur objectifs spécifiques et la classe de langue. Paris: Clé International.

CORBIN, J. \& STRAUSS, A. (2015). Basics of qualitative research. Techniques and procedures for developing grounded theory. Thousand Oaks: Sage Publications.

DvoŘÁKovÁ, K. (2018). La simulation globale dans le cours de français de la diplomatie et des relations internationales. Synergie Europe, ročník neuveden (13), 85-95.

HENDRICH, J. (1988). Didaktika cizích jazyků. Praha: SPN.

Huber-Kriegler, M., LÁzÁR, I., \& STRANGe, J. (2005). Miroirs et fentres - Manuel de communication interculturelle. Strasbourg: Conseil de l'Europe.

KováŘová, D. (2014). Différences interculturelles franco-tchèques en français des affaires. Xlinguae, 7(3), 92-100.

MANGIANTE, J.-M. \& PARPETTE, C. (2004). Le français sur objectifs spécifique: de l'analyse des besoins à l'élaboration d'un cours. Paris: Hachette.

Mourlhon-Dallies, F. (2008). Enseigner une langue à des fins professionnelles. Paris: Didier.

MYLES, J. (2009). Oral competency of ESL technical students in workplace interships. Teaching English as a Second Foreign Language, 13(1), stránkování neuvedeno. [Online]. c2018 [vid. 23. 8. 2018]. Dostupné z https://files.eric.ed.gov/fulltext/EJ898196.pdf

NiKYEMA, P., \& HENRY, K. (2009). Projet Valeurtech: préparation à une mobilité en entreprise en Europe à partir des compétence attendues du technicien supérieur. Cahier d'APLIUT, 28(1), 105-111.

PÉGAZ-PAQUET A. (2016). L'interculturel en question: trois cas d'intégration à un programme de Master of Science, Marché de l'art et négociation à l'international, à Institut des hautes études économiques et commerciales (INSEEC). Synergie, 9, 95-105.

Peyrard-Zumbihl, H. (2004). Anglais de spécialité et acquisition de la compétence de médiation culturelle en milieu universitaire. (Disertační práce). Nantes: Université de Nantes.

RichaRdS, J. C., \& RoDgers T. S. (2014). Approaches and methods in language teaching. Cambridge: Cambridge Universitey Press.

ŘıHÁČEK T., \& HYTYCH, R. (2013). Metoda zakotvené teorie. In T. ŘıHÁČEK, I. ČERMÁK, R. HYTYCH (Eds.), Kvalitativní analýza textů: čtyři prístupy. (s. 44-74). Brno: MUNI Press.

Trofin, R. A. (2018). L'interculturel - facteur clé d'une bonne insertion professionnelle. Synergie, 13, 97-105.

YAICHE, F. (1996). Les simulations globales. Mode d'emploi. Paris: Hachette.

\section{Autorka}

Mgr. Ing. Hana Delalande, Katedra francouzského jazyka a literatury, Pedagogická fakulta Masarykovy univerzity, e-mail: delalande@ped.muni.cz

Autorka je vyučující odborné francouzštiny a geografie v bakalářském studijním programu Francouzský jazyk pro hospodářskou činnost na KFJ PdF MU a zároveň studentkou doktorského programu Didaktika cizího jazyka (od r. 2017). Specializuje se na rozvoj interkulturní komunikační kompetence u studentů učitelství a u studentů vyjíždějících na zahraniční stáže, na mezinárodní mobilitu a na některé složky odborné francouzštiny (obchodní korespondenci, francouzštinu pro specifické účely). Zúčastnila se několika odborných konferencí v České republice, v Mad’arsku a na Slovensku a absolvovala rovněž výzkumné pobyty ve Francii (Université de Nantes, IPAG - Université Rennes 1). 